\title{
Gastrointestinal parasites of wild blue-fronted amazons in Chaco, Argentina
}

Berkunsky, I. ${ }^{1}$; Ruggera, R.A. ${ }^{2}$; López, M.S. ${ }^{3}$; Faegre, S.I. ${ }^{4}$; Aramburú, R.M. ${ }^{5}$

${ }^{1}$ Instit. Multidiscipl. Ecosist. Desarr. Sust. (CIC-CONICET, Univ. Nac. Cent. Pcia. Bs.As, Tandil, Argentina). ${ }^{2}$ Inst. Ecoreg. Andinas (Jujuy, Argentina). ${ }^{3}$ Centr. Estud. Parasit. (La Plata, Argentina). ${ }^{4}$ Rota Avian Behav. Ecol. (Washington, USA). ${ }^{5}$ Div. Zool. Verteb. UNLP (La Plata, Argentina). E-mail: igorberkunsky@gmail.com

\begin{abstract}
Berkunsky, I.; Ruggera, R.A.; López, M.S.; Faegre, S.I.; Aramburú, R.M.: Gastrointestinal parasites of wild blue-fronted amazons in Chaco, Argentina. Rev. Vet. 30: 2, $X X-X X, 2019$. From capture to final destination, wild parrots experience several conditions during transport which enhance/promote chances of infections and transmission of diseases. A better understanding of the prevalence of parasites in wild blue-fronted amazons (Amazona aestiva) will allow a more efficient control of the parasitosis in those individuals destined to captivity. Furthermore, it will be helpful in determining which parasites are specific to the blue-fronted amazons and which are the result of infections from other host species during the commercialization process. The objective of this study was to establish the baseline of gastrointestinal parasites of wild blue-fronted amazons in the Chaco region. We collected fecal samples of 38 nestlings and 4 adults, and examined four dead nestlings. One-third of examined nests $(n=21)$ and one quarter of the individuals examined were positive for protozoa and helminths. At the individual level, Eimeria sp was the most prevalent (25\%), followed by Isospora sp (5\%), Giarda lamblia (5\%), Capillaria sp (2\%) and Ascaridia sp (2\%). The tests for parasites in the viscera of the four nestlings found dead from natural causes weres negative. As in most wild studies, the prevalence of intestinal parasites in blue-fronted amazons was low, when compared to the parasitic infection levels reported for parrots in captivity. Because the nestlings of this parrot are frequently captured for pet trade, knowledge of the assemblage and prevalence of intestinal parasites of the species in wild individuals can be useful for the treatment of nestlings destined for captivity.
\end{abstract}

Key words: blue-fronted parrot, Ascaridia, Capillaria, Eimeria, coccidian.

Recibido: marzo 2019 / Aceptado: mayo 2019

This work was supported by CONICET (PIP 112-20110-00358 y 112-20150100598CO), ANPCYT (PICT 2011-0173 y 2015-2288), UNLP (grants: 11/n572, 1/n702) and UNCPBA, IdeaWild, Birder's Exchange, Parrot People Foundation, The World Parrot Trust, The Amazona Society, and Parrots International.

\section{Resumen}

Berkunsky, I.; Ruggera, R.A.; López, M.S.; Faegre, S.I.; Aramburú, R.M.: Parásitos gastrointestinales de loros habladores silvestres en Chaco, Argentina. Rev. Vet. 30: 2, $X X-X X, 2019$. Desde su captura hasta el destino final, los loros silvestres experimentan diferentes condiciones durante el transporte, originando así oportunidades de infec- 
ción y transmisión de enfermedades. Conocer la prevalencia de parásitos en loros habladores silvestres (Amazona aestiva) permitirá un control más eficiente de las parasitosis en aquellos individuos destinados al cautiverio. Además, este trabajo ayudará a determinar qué parásitos son específicos del loro hablador, y cuales son los resultados de infecciones desde otras especies hospedadoras durante el proceso de comercialización. El objetivo de este estudio fue describir los parásitos gastrointestinales de los loros habladores en la región del Impenetrable Chaqueño, en Argentina. Fueron colectadas muestras de heces de 38 pichones y cuatro adultos. También se examinaron cuatro pichones muertos. Un tercio de los nidos inspeccionados $(\mathrm{n}=21)$ y un cuarto de los individuos examinados fueron positivos a la presencia de protozoos y helmintos. A nivel individual, Eimeria sp fue el parasito más prevalente (25\%), seguido de Isospora sp (5\%), Giardia lamblia (5\%), Capillaria sp (2\%) y Ascaridia sp (2\%). Las inspecciones en busca de parásitos en las vísceras de los cuatro pichones hallados muertos por causas naturales, fueron negativas. Como en la mayoría de los estudios con loros silvestres, la prevalencia de parásitos intestinales en el loro hablador fue baja, si se compara con los valores reportados para loros en cautiverio. Debido a que los pichones de este loro son capturados frecuentemente para el tráfico de mascotas, conocer el ensamble de parásitos intestinales y su prevalencia en individuos silvestres, puede ser útil para el tratamiento de pichones destinados al cautiverio.

Palabras clave: loro hablador, Ascaridia, Capillaria, Eimeria, coccidios.

\section{INTRODUCTION}

The blue-fronted amazon (Amazona aestiva) is one of the most common species of parrots in captivity and for many years large numbers of wild individuals have been captured to supply the global pet market (Rev. Hornero 27: 39-49). In Argentina, the trapping of blue-fronted amazons for the live bird trade reached its peak during the 80's when more than half a million wild individuals were sold on the pet market, placing this parrot among the most frequently traded Psittacidae species worldwide ${ }^{4}$.

From 1998 until 2012, the national fauna authority of Argentina coordinated the removal of more than 20,000 wild nestlings and 5,400 wild adults from the Chaco forest in northern Argentina ${ }^{1}$.

From their capture to their final destination, the wild parrots experience several conditions in captivity which include: overcrowding, food contamination, and close contact with other species, among others ${ }^{9}$. These conditions make parrots vulnerable to both disease infection and transmission, for example with gastrointestinal parasites are common, and this is the reason why captive parrots usually report higher prevalence and larger numbers of parasite species than wild individuals ${ }^{5,8}$.

Studies providing information about intestinal parasites in blue-fronted amazons, were conducted mostly in captive individuals, whereas the scarce number of studies reporting gastrointestinal parasites in wild parrots usually involved few individuals, and report low values of prevalence ${ }^{2,3}$.

The objective of this study was to establish the baseline of gastrointestinal parasites affecting a wild population of the blue-fronted amazon occurring in the Chaco region, to allow a more efficient control of the parasites in those individuals destined for captivity. Additionally, this work will assist in determining which parasite species are 
specific to the blue-fronted amazon and which are the result of infections from other host species during the commercialization process.

\section{MATERIAL AND METHODS}

The field research was conducted between December 2004 and January 2005 in the Loro Hablador Provincial Park ( $\left.25^{\circ} \mathrm{S}, 62^{\circ} \mathrm{W}\right)$, Province of Chaco, Argentina. Parrot nestlings were hand captured and then manually restrained for physical examination and biomaterial collections.

All nestlings were handled for approximately 10 minutes for body weight, physical examination, and blood collection. After sample and data collection, and after confirm that nestlings were in a good health condition, birds were released back into their nest.

We collected between three to five repeated fecal samples of each nestling for a total of 38 evaluated nestlings from 21 nests. We also obtained one single fecal sample (not repeated) from four adult females. Fecal samples were collected opportunistically from all individuals that defecated during handling or within minutes of defecation, if observed.

The fecal samples were stored in a $10 \%$ formaldehyde solution and maintained at room temperature for a maximum of 10 days, until arriving at the laboratory. We used two techniques to detect eggs and cysts of parasites in the fecal samples: the ether sedimentation and the simple levitation methods ${ }^{6}$.

We split four sub-samples per each sample, and then observed them at 100x and 400x in an optical microscope. Additionally, with the aid of a stereoscopic binocular microscope, we examined the viscera of four nestlings which were found dead inside the nest, searching for adult helminths.

We calculated the prevalence of each parasite as the number of hosts parasitized by the parasitic species divided by the total number of hosts examined (expressed as a percentage).

\section{RESULTS AND DISCUSSION}

More than one third (38\%) of the nests had at least one parasitized nestling. One quarter of the nestlings (26\%) had at least one species of intestinal parasite, and the number of parasite genera were 1.25 genera per nestling.

The most common parasites were coccidia (Eimeria sp $21 \%$ of prevalence), while flagellates (Giardia sp 5\% of prevalence) and helminths (Ascaridia sp 3\%, and Capillaria sp 3\% of prevalence) appeared only in two and one nestlings respectively.

Two of the four adult parrots were parasitized by two coccidia taxa (Eimeria sp and Isospora sp). We did not find helminths in adult feces. The examinations of the viscera of the four nestlings found dead from natural causes were also negative.

Our findings support results reported by other studies in which endoparasites have been found at relatively low levels in free-ranging parrot species ${ }^{2,7}$. However, our observed prevalence values were slightly higher than previous studies. This could be related to the fact that we took fecal samples in a serial manner, increasing the probability of detecting the eggs and oocysts due to sampling at different points in the parasite species’ life cycles. 
We found five genera of parasites between protozoa and helminths, all of which have been previously reported in wild blue-fronted amazons. Coccidia (Eimeria sp and Isospora sp) are very host specific, non motile protozoa found in the intestinal mucosa of most parrot species around the world. Eimeria aestivae was described in the bluefronted amazon ${ }^{3}$. Isospora is a common parasite in passerine birds, but it also has a few records in domestic parrots ${ }^{3}$.

Helminths (Ascaridia sp and Capillaria sp) have a direct life cycle; ingestion of contaminated food, water, and feces is the route of transmission. These two genera were found only one blue-fronted amazons in Bolivia from eight wild adults analyzed ${ }^{3}$.

The feeding habits of the blue-fronted amazon (i.e. consumption of fruits and seeds in the tree canopy) make the risk of transmission by contaminated food very low, and therefore low numbers of these intestinal parasites would be expected.

Acknowledgements. We are grateful to R.Rojas, J.Carrera, B.Charpin, C.Fourniére, L.Pagano, K.Jones, H.Povedano, F.Kacoliris, and all volunteers for partnership and collaboration during field and laboratory work. We also thank the Dirección de Fauna, Parques y Ecología of Chaco Province and the park-rangers of Loro Hablador Provincial Park for logistical support.

\section{REFERENCES}

1. Bolkovic ML, Ramadori D. 2006. Manejo de fauna silvestre en la Argentina. Programas de uso sustentable. Dirección de Fauna Silvestre, Secretaría de Ambiente y Desarrollo Sustentable, Buenos Aires. http://www.academia.edu/4033473/Manejo _de_Fauna_Silvestre_en_la_Argentina.

2. Deem SL, Noss AJ, Cuellar RL, Karesh WB. 2005. Health evaluation of freeranging and captive blue-fronted amazon parrots (Amazona aestiva) in the Gran Chaco, Bolivia. J Zoo Wildlife Med 36: 598-605.

3. Hofstatter PG, Guaraldo AM. 2011. A new eimerian species (Apicomplexa: Eimeriidae) from the blue-fronted amazon parrot Amazona aestiva L. (Aves: Psittacidae). Brazil J Parasitol 97: 1140-1141.

4. Rabinovich JE. 2005. Management in the face of multiple uncertainties. In: Biodiversity and the precautionary principle (Cooney R, Dickson B, Ed.). Earth Scan, London, p. 173-188.

5. Ravich ML, Reavill DR, Hess L, Childress AL, Wellehan JF. 2014. Gastrointestinal cryptosporidiosis in captive psittacine birds in the United States: a case review. J Avian Med Surg 28: 297-303.

6. Ritchie LS. 1948. An ether sedimentation technique for routine stool examinations. Bulletin of U.S. Army Medicine Department 8: 326.

7. Rooney MB, Burkhard MJ, Greiner E, Zeng QY, Johnson J. 2001. Intestinal and blood parasites in Amazon parrots destined for relocation in Guatemala. J Zoo Wildl Med 32: 71-73.

8. Valdebenito JO et al. 2015. Gastrointestinal and external parasites of Enicognathus ferrugineus and Enicognathus leptorhynchus (Aves, Psittacidae) in Chile. Rev Bras Parasitol Vet 24: 422-431.

9. Weston MK, Memon MA. 2009. The illegal parrot trade in Latin America and its consequences to parrot nutrition, health and conservation. Bird Populat. 9: 76-83. 